\title{
The effect of polishing agents on the transverse strength of heat cured acrylic resin bases
}

\author{
${ }^{1}$ Tiysha Suraskurmar, ${ }^{2}$ Syafrinani \\ ${ }^{1}$ Student at professional stage \\ 'Lecturer at Department of Prosthodontic \\ Faculty of Dentistry, University of Sumatera Utara \\ Medan, Indonesia \\ Corresponding author: Tiysha Suraskurmar, email: tiyshasuraskumar@gmail.com
}

\begin{abstract}
Introduction: Heatcured acrylic resin is frequently used denture base material whereby transverse strength is one of the mechanical properties that must be observed. A rough surface absorbs water, reduces strength of denture bases, thus polishing should be done. Pumice is the most abrasive material used in dentistry. Eggshell and toothpastecan be used as alternative abrasive materials. This study aims to determine the differences in value of transverse strength of HCA resin once polished using pumice, eggshells, and toothpaste. Method: This laboratory experimental study using sample sized $65 \times 10 \times 2.5 \mathrm{~mm}$ with 30 samples in total for 3 groups. Transverse strength was measured using Universal Testing Machine. The data were analyzedusing one-way Anova. Result:The comparison ratio of transverse strength between $\mathrm{HCA}$ resin after polishing with pumice, eggshells and tooth paste is 93.63 : 118.42 : $105.91 \mathrm{MPa}$. It shows there were significant differences in transverse strength between groups with significant value pwas 0.001 which less than 0.05 . Conclusion: The value of transverse strength varies according to polishing material used. Eggshell has the highest transverse strength value compared to pumice and toothpaste. Key words: heat cured acrylic resin, denture bases, transverse strength, polishing materials
\end{abstract}

\section{INTRODUCTION}

Since first polymerized in 1936 by Walter Bauer, heat cured acrylic resin became the most commonly used denture base material because it is inexpensive, ease processing, good color stability and easy to polish. ${ }^{1,2}$ One of the characteristics of heat cured acrylic resin that should be observed is the mechanical properties which is the transverse strength. ${ }^{2}$ The minimum transverse strength of denture base materials should not be less than $65 \mathrm{MPa} .^{3}$ The transverse strength of acrylic resins depends on several factors such as polymer molecular weight, residual monomerlevel, plasticizer composition, denture base thickness, type of polishing and porosity. ${ }^{4}$ Rough surfaces increases water absorption because water acts as a plasticizer untilacrylic resin material becomes soft and flexible. ${ }^{5,6}$ To get a smooth surface, polishing process should be done. Traditionally, acrylic resin is polished by mechanical procedure using abrasive materials because it produces a smoother base surface. Abrasive material that is often used as a polishing material in the field of dentistry is pumice. Pumice is the powdered form of volcanic rock that has a holey texture. ${ }^{7}$ Pumice consists of $60-67 \%$ silica, $13-17 \%$ alumina, $7-8 \%$ sodium oxide-potassium oxide and minimal amount of iron oxide, calcium oxide and titanium dioxide. ${ }^{8}$

Other alternative abrasive materials that can be used as polishing agent are eggshelland toothpaste. The eggshell is the outer part of the egg with a hard and porous texture consisting of $94 \%$ calcium carbonate, $1 \%$ magnesium carbonate, $1 \%$ calcium phosphate and $4 \%$ organic matter. ${ }^{9}$ Henuset states calcite from calcium carbonate has abrasive properties which can be used to polish the surface of acrylic resins. ${ }^{10}$

Toothpaste is generally used for tooth surfaces and mechanical cleaning of artificial teeth. Toothpaste contains a variety of abrasive substances such as calcium carbonate, dicalcium phosphate, alumina, calcium pyrophosphate, sodium bicarbonate, perlite and silica. Generally, the abrasive material in a toothpaste is around $20-55 \% .{ }^{11}$ According to Hefferen and Forward, abrasive material is added to toothpaste to remove plaque, stain and food debris. ${ }^{12}$ According to Pisani etal, toothpaste has polishing effect on the surface of acrylic resindenture bases because of the silica content. ${ }^{13}$

Based on this, the idea arose to utilize eggshells and toothpaste as a polishing agent for heat cured acrylic resin bases.

\section{METHOD}

In this experimental laboratory research,the eggshells were collected from various food outlets, washed under running water and then soaked for 6 hours in $2.5 \%$ sodium hypochlorite solution. Eggshells were dried using electric oven (Naberthem, USA) for 6 minutes at $250^{\circ} \mathrm{C}$. The eggshells were crushed with a blender and $15 \mathrm{~g}$ of sodium lauryl sulfate added to $300 \mathrm{~g}$ of eggshelland blended until 
homogeneous. The use of ball-mill (Retsch PM200 Series, Germany) to produce fine particlesize was carried out for 60 minutes at a speed of $400 \mathrm{rpm}$. The powder was then sieved with mesh 100 and continued with mesh 400 .

Samples were made from $\mathrm{HCA}$ resin of size $65 \times 10 \times 2.5 \mathrm{~mm} .3,5$ The total number of sample was 30 and divided into 3 groups:the pumice group, the eggshell group and the toothpaste group. The cuvette containing the mold comes from the parentmodel which was planted in a cast. The mold was filled with acrylic resin dough then the cuvette was closed, pressed then cured in a water bath. Samples were removed from the cuvette and trimmed with a fraser bur, grinded with 400, 800 and 1200 sandpaper using a rotary grinder and followed bypolishing using a rag wheel mounted to polishing motor, using pumice, eggshell and toothpaste. Each sample was polished for 2 minutes, then were immersed in distilled water for 2 days at $37^{\circ} \mathrm{C}$ in an incubator (Memmert, Germany).

Transverse strength testing was performed using the Universal Testing Machine (Torsee's Electronic System). Dataanalysis was performed with Univariate test and one-way Anova test.

\section{RESULT}

The results show that the value of transverse strength analyzed by the Univariate test whereby the pumice group has a mean value of $93.63 \mathrm{MPa}$ and with a standard deviation of 10.22 . The mean value of eggshell group was $118.42 \mathrm{MPa}$ with a standard deviation of 12.66 . The mean value of the toothpaste group was $105.91 \mathrm{MPa}$ with a standard deviation of 9.80. Based on the one-way Anova test, therewere significant differences in the value of transverse strength in the three groups with a value of $p$ was 0.001 , less than 0.05 (Table 1 ).

Table 1 Anova test results on the value of transverse strength between the pumice, eggshell and toothpaste groups.

\begin{tabular}{cccc}
\hline \multirow{2}{*}{ Groups } & \multicolumn{3}{c}{ Transverse Strength (MPa) } \\
\cline { 2 - 4 } & $\mathrm{n}$ & $\bar{x} \pm \mathrm{SD}$ & $\mathrm{p}$ \\
\hline Pumice & 10 & $93,63 \pm 10,22$ & \\
Eggshell & 10 & $118,42 \pm 12,66$ & $0,001^{*}$ \\
Toothpaste & 10 & $105,91 \pm 9,80$ & \\
\hline
\end{tabular}

Note: *significant

Based onleastsignificant difference (LSD) test, the value of transverse strength between the pumice group and the eggshell group with a value of pwas 0.001 ; less than 0.05 , the pumice group with toothpaste group with a value of $p$ was 0.019 ; less than 0.05 , eggshell with toothpaste group with $p$ value was 0.017 ; less than 0.05 (Table 2).

Table 2 LSD test results for each group

\begin{tabular}{cccc}
\hline & Pumice & Eggshell & Toothpaste \\
\hline Pumice & - & $0.001^{*}$ & $0.019^{*}$ \\
Eggshell & $0.001^{*}$ & - & $0.017^{*}$ \\
Toothpaste & $0.019^{\star}$ & $0.017^{\star}$ & - \\
\hline Note: ${ }^{\star}$ significant & & &
\end{tabular}

The results show that the three groups have transverse strength values above the standard value accepted in dentistry, which is $65 \mathrm{MPa}$. Based on the statistical test results, the eggshell group has the highest transverse strength value compared to the pumice group and toothpaste group. There was a significant difference between the eggshell group with the pumice group and toothpaste group.

\section{DISCUSSION}

The results show that the value of transverse strength varies in the samegroup. The acquisition of these varied results can be caused by a rough surface that increases the capacity of water absorption. ${ }^{6}$ Acrylic resins have the characteristics of absorbing waterslowly over a period of time by the mechanism of water absorption through the diffusion of water molecules according to the diffusion law. Absorption occurs because water molecules penetrate the mass of polymethyl methacrylate and occupy the positions between the polymer chains which causes disruptions to the polymerchains. ${ }^{14}$ The water absorbed acts as a plasticizer which affects the surface hardness, dimensional stability, colour stability, fatigue limit and transverse strength. ${ }^{5}$

ResearchbyHasanah shows that the surface roughness values of HCA resin polished with alumina were $0.3488 \pm 0.0767 \mu \mathrm{m} .{ }^{15}$ Sahin stated that HCA resin polished with aluminaand immersed in aquades for 2 days produces tranversestrength value of $64.27 \pm 4.30 \mathrm{MPa} .{ }^{16}$ The acquisition of alow transverse strength value is due to the rough surface of the acrylic resin resulting in high water absorption. Study conducted by Oliviera obtained that the HCA resin polished with pumice and chalk resulting in surface roughness value of $0.0427 \pm$ $0.25 \mu \mathrm{m} .{ }^{17}$ Braunstated that the HCA resin polished with pumice and chalk and soaked in aquades for 2 days resulted in a transverse strength value of $89.05 \pm 0.73 \mathrm{MPa} .{ }^{18}$ The acquisition of hightransverse strength value is due to the smooth surface of acrylic resin resulting in low water absorption. This is supported by Rahal et al stating that high water absorption occurs on rough surfaces where 
water enters through the surface porosity of acrylic resin after polishing. ${ }^{19}$

Based on the data obtained, the mean and the standard deviation value of transverse strength of pumice groupwas $93.63 \pm 10.22 \mathrm{MPa}$. The value of transverse strength of eggshell group was $118.42 \pm 12.66 \mathrm{MPa}$. The transverse strength value of toothpaste groupwas $105.91 \pm 9.80 \mathrm{MPa}$. From the one-way Anova test in Table 1, it can be seen that there were minimal significant differences in the two groups because the significance of $p$ was 0.001 and less than 0.05 .

The pumice group has transverse strength value above the standard required in dentistry. In this study, the pumice group has a mean transverse strength value of $93.63 \pm 10.22 \mathrm{MPa}$, this value was not much different from previous study which had a transverse strength value of 94.77 $\pm 9.45 \mathrm{MPa} .{ }^{4}$ Although the value of transverse strength in the pumice group is more than the required standard value but the value is lower than the eggshell and the toothpaste group due to the high waterabsorption in the pumice group. Water absorption occurs on rough surfaces where water enters through the surface porosity on acrylic resin. ${ }^{19}$ Yudi's study obtained that the HCA resin polished with pumice results in higher surface roughness value compared to eggshell and toothpaste group. ${ }^{20}$ This is due to the differences in particle size, particle shape, particle hardness and abrasive material content of each polishing agent is different. ${ }^{10,13}$ Pumice with an irregular particle shape has a particle size of 5-8 $\mu \mathrm{m}$ and particle hardness of 6-7 according to the Mohs scale. High particle hardness and size produces higher surface roughness of acrylic resin, to the extend that when acrylic resin is immersed in distilled water, high water absorption occurs and the transverse strength decreases because water acts as a plasticizer which results in HCA being flexible.

The eggshell group has a mean transverse strength value of $118.42 \pm 12.66 \mathrm{MPa}$ higher than the pumice and toothpastegroup. Yudi's research found thateggshell produces smoother surface. ${ }^{20}$ According to Areeg \& Bassam et al, physical properties of abrasive materials such as particle size and hardness are directly proportional to the quality of surface roughness. ${ }^{10}$ In this study, ball mill was used for 60 minutes. Wu SC et al stated that grinding eggshell using a ball mill for 60 minutes can produce an average particle size of $2.21 \mu \mathrm{m}$. Based on that study, it was known that longer grinding time with aballmill produces smaller particle size..$^{21}$ The hardness of eggshell particle is
4 according to Mohs scale. Smaller particle size and lowerparticle hardness of polishing materials have an advantage that is to produce smoother surface. In addition, the abrasiveness of eggshell material is influenced by the calcite content in calcium carbonate ranging $94-98.2 \%$, calcite acts as an abrasive. ${ }^{10}$ With this, the water absorption that occurs in acrylic resin is low. This results in acrylic resin having great strength and being able to reduce deflection when force is applied which produces high transverse strength value.

The toothpastegroup has a transverse strength value of $105.91 \pm 9.80 \mathrm{MPa}$. Yudi's study found thattoothpasteshoweda lower surface value than pumice group buthigher surface roughness value than eggshell group. ${ }^{20}$ Pisani et al after experimenting the effect of abrasive toothpaste on surface roughness of acrylic resin, stated that toothpaste which contains silica has polishing effect on the surface of denture bases. ${ }^{13}$ The shape of the toothpasteparticle is square orslightly rounded and the hardness of the particles according to the Mohs scale is $5 .{ }^{22}$ Although the amount of abrasive material in toothpaste ranges $20-55 \%$, it is less than the pumice and eggshell group which makes the abrasive ability of toothpaste to be low thus the effectiveness when polishing is reduced, however the particle size is smaller than pumice and eggshell group which is an advantage for the toothpaste group. Toothpaste produces smoother surface compared to pumice group. Water absorption is high, thus resulting in lower transverse strength value compared to eggshell buthigher transverse strength value than pumice group.

The LSD test shows a significant difference between the pumice group and eggshell group with $p$ was 0.001 , pumice group and toothpaste group with $p$ was 0.019 and the eggshell group with the toothpaste group with a value of $p$ was 0.017 . Based on this, it can be statistically seen that the 4 eggshell group produced the highest transverse strength value compared to pumice and toothpaste group, while the toothpaste group produced higher transverse strength value compared to pumice group. Eggshells have an advantage, whereby is has the highest amount of abrasive material compared to other polishing material in which it has calcium carbonate content 94$98.2 \% .^{10}$

Clinically, the standard transverse strength value of denture base is not less than $65 \mathrm{MPa}$. Based on this, all three groups have fulfilled the standard transverse strength value requirement. 
Pumice is the most widely used polishing material foracrylic resins because it has been proven that the transverse strength is more than $65 \mathrm{MPa}$, however the transverse strength value is still not better compared to eggshell and toothpaste. Eggshell produces better transverse strength value compared to pumice and toothpaste. Toothpaste produces better transverse strength value com- pared to pumice, however it is still not better compared to eggshell.

It was concluded that the use of different polishing materials on heat cured acrylic bases has an influence on the value of transverse strength. Heat cured acrylic resin which was polished using eggshell has higher transverse strength value than that which was polished using pumice and toothpaste.

\section{REFERENCES}

1. Khindira SK, Mittal S, Sukhija U. Evolution of denture base materials. J Indian Prosthodont Soc 2009; 9(2):64-9

2. McCabe JF, Walls AWG. Applied dental materials.9th ed. London: Blackwell Munksgaard; 2008.p.110-23

3. Watri D. Pengaruhpenambahan seratkacapadabahan basis gigtiruan resinakrilik polimerisasi panasterhadap kekuatan impakdantransversal [Skripsi]. Medan:Fakultas Kedokteran Gigi Universitas Sumatera Utara, 2010: 36-7.

4. Orsi IA, Andrade VG. Effect of chemical disinfectants on the transversal strength of heat-polymerized acrylic resins submitted to mechanical and chemical polishing. J Prosthet Dent 2004; 92: 382-8

5. Hemmati MA, Vafaee F, Allahbakhshi. Water sorption and flexural strength of thermoplastic and conventional heat-polymerized acrylic resins. J Dent, Tohran University of Medical Sciences 2015; 12(7): 478-9.

6. Utami M, Febrida R, Djustiana N. The comparison of surface hardness between thermoplastic nylon resin and heat-cured acrylic resin. Padjajaran J Dent 2009; 21(3): 200-3.

7. AL-Kheraif. The effect of mechanical and chemical polishing techniques on the surface roughness of heatpolymerized and visible light-polymerized acrylic denture base resins. Saudi Dent J 2014, 56-62

8. Manapallil JJ. Basic dental materials. $4^{\text {th }}$ ed. New Delhi: Jaypee Brothers Medical Publishers (P); 2016.p. $532-52$

9. Murakami FS, Rodrigues PO, de Campos CMT, Silva MAS. Physicochemical study of $\mathrm{CaCO} 3$ from eggshells. Ciencia Tecnol Aliment 2007: $27: 658-62$.

10. Onwubu SC, Vahed A, Singh S, Kanny KM. Using eggshell for development of a quality alternative material to pumice in reducing the surface roughness of heat-cured acrylic resins [Thesis]. Johanesburg: Durban University; 2016: 6-14,23-5,34-5,49

11. Joiner A. Whitening toothpaste: A review of the literature. J Dent 2010: e17-24

12. Herda E, Fawzia AF, Soufyan A. Pengaruh penyikatan dengan pasta gigi terhadap kekasaran permukaan nano-ionomer dan semen ionomer kaca modifikasi resin. JMKG 2012; 1(1): 23-32

13. Pisani MX. Evaluation of the abrasiveness of dentifrices for complete dentures. J Prosthodont 2010, 25; 19 : 369-73

14. Pantow FPCC, Siagian KV, Pangemanan DHC. Perbedaan kekuatan transversal basis resin akrilik polimerisasi panas pada perendaman minuman beralkohol dan aquades. E-Gigi J 2015; 3(2): 398-402.

15. Hasanah N, Triaminingsih S, Matram N. Karakterisasi kekasaran permukaan resin akrilik polimerisasi panas dengan serat dan tanpa serat [Skripsi]. Fakultas Kedokteran Gigi Universitas Indonesia; 2014. p.1-11.

16. Sahin C, Ergin A, Ayyildiz S, Uzun G. Evaluation of flexural strength and Candida albicans adhesion of an acrylic resin repaired with 4 different resin materials. Clin Dent Res 2012; 36(2): 10-4.

17. Oliviera LV, Mesquita MF, Henriques GEP. Effect of polishing technique and brushing on surface roughness of acrylic resins. J Prosthodont 2008; 17: 308-11.

18. Braun KO, Mello JAN, Rached RN, Del Bel Cury AA. Surface texture and some properties of acrylic resins submitted to chemical polishing. J Oral Rehabil 2003; 30: 91-8.

19. Rahal JS, Mesquita MF, Henriques GEP. Influence of chemical and mechanical polishing on water sorption and solubility. Braz Dent J 2004; 15(3): 225-30.

20.Setiawan Y. Perbedaan kekasaran permukaan basis resin akrilik polimerisasi panas menggunakan bahan pumis, cangkang telur dan pasta gigi sebagai bahan poles [Skripsi]. Program Sarjana Fakultas Kedokteran Gigi Universitas Sumatera Utara.

21. Wu SS, Hsu HC, Hsu SK, Chang YC, Ho WF. Synthesis of hydroxyapatite from eggshell powders through ball milling and heat treatment. J Asian Ceram Soc 2015; 198: 1-6.

22.Sumendap IB, Herda E, Eriwati YK. Effect of whitening toothpaste on the discoloration level of stained conventional glass ionomer cement. J Phys: Conf Ser 2018; 1073: 1-6. 